\title{
On Translation Quality of Mongolian Intangible Cultural Heritages: The Mausoleum of Genghis Khan as a Case Study*
}

\author{
Jinyu Liu \\ Inner Mongolia University, Hohhot, 010021, China \\ Meiling Wen \\ Inner Mongolia University, Hohhot, 010021, China
}

\begin{abstract}
With the globalization of tourist industry, cultural and historical heritages are seen as the basic tourism resources. The quality of English translation of those resources plays an important role in valid cultural exchanges and boom of tourism industry. Mongolian cultural heritage presents a rich cultural resource and unique tourism value. Quite often it contains many terms and notions with specialized connotation which are rather difficult for target readers to comprehend and interpret. This paper takes the Mausoleum of Genghis Khan as a case study to analyze the translations of specific cultural words and sentences. Based on the current translation problems arising from the practical English translation of the materials about the Mausoleum, it aims to put forward some suggestions and to explore the effective translation strategies to further improve translation quality.
\end{abstract}

Index Terms - cultural heritage, foreign publicity, translation strategies and methods, the Mausoleum of Genghis Khan

\section{INTRODUCTION}

The swift and violent development of globalization and modernization has stimulated rapid development of tourism industry and has improved contemporary self-consciousness urging people to care about historical and cultural heritage. Ethnical historical and cultural heritage enjoys a long splendid history in China, with tight spirit and harmonious relationships. In 2011, the Publicity Office of the CPC Central Committee, Minister of the State Council Information Office and National Tourism Administration signed an agreement which emphasized the necessity that foreign publicity promotes tourism while tourism deepens development of foreign publicity. As the essential medium and bridge of foreign publicity, the Chinese-English translation is very important.

Inner Mongolia pushes its tourism industry in a broad way, and attracts visitors from all over the world with its natural beauty, typical regional customs and unique national characteristics. According to the data from Inner Mongolia Tourism Administration, during the Eleventh Five-Year Plan period, Inner Mongolia Autonomous Region has received more than 6.99 million tourists from overseas, up by $7.35 \%$ per year, and foreign exchange earnings from tourism has topped 2.186 billion. The number of overseas visitors increases unceasingly every year, however, owing to insufficient foreign publicity on tourism, and lack of recognition of the importance of Chinese-English translation in the process of tourism publicity, Inner Mongolia's whole image is faint and lacks of brand effect. Therefore, improving the translation level of tourism material is inevitable to drive Inner Mongolia's tourism development. The Mausoleum of Genghis Khan is a place worshiped by the whole Mongolians. It is a grassland culture tour sight and is an important national cultural relic unit. It is also one of the Top-Forty Tour Sights of China, one of the Top-Hundred Patriotism Education Base and one of the national 5A-level beauty spots. This paper will take Genghis Khan's Mausoleum as an example to study the $\mathrm{C}-\mathrm{E}$ translation of national historical and cultural heritage.

The paper begins with a review, which includes the significance and research status of $\mathrm{C}$-E translation of national historical and cultural heritage publicity, and then introduces language characteristics and style differences between Chinese and English publicity materials. After that, the author will analyze the translation of tourism materials of the Mausoleum of Genghis Khan and discuss translation strategies, such as addition, omission, combination and division, the combination of transliteration and semantic translation; and also investigate shortcomings of its translation, such as spelling mistakes, grammar errors, mistranslation, pinyin translation without annotation, and so on. The last part is about suggestions for improving the quality of tourism translation.

\footnotetext{
* This paper marks a stage in a research that was made possible by the Philosophy and Social Sciences Research Planning Office of Inner Mongolia, China (program No.2011C027), and supported by the China National Committee of MTI Education (program No.MTIJZW201411) as well. I wish here to renew my thanks to both the committees that saw the interest of this research not only for the case study at hand, but for reflecting on a field of translation studies.
} 


\section{The Current Status and Significance of Translation of Cultural Heritage Publicity}

Tourism plays a positive role in the national economy. With the development of economic globalization, international tourism develops very fast. Cultural heritage as the most important tourism resource is the symbol of the history of all nationalities in China, and it is the base for sustainable development of tourism. Therefore, the foreign publicity of cultural heritage is a key factor in promoting the development of tourism globalization. At the same time, the combination of the publicity and tourism development can protect cultural heritage and express the unique charm and human values (Zheng, 2013, p.181). As an important means of foreign publicity, translation is playing an important role in improving cultural exchanges and in protecting cultural diversity. Therefore, we must pay close attention to the English translation of national historical and cultural heritage.

In order to spread unique ethnic culture and promote tourism development in the international market, Inner Mongolia has sent delegations to take part in the World Travel Market conferences with well- prepared travelling products with special Mongolian features, and with Inner Mongolia tourism documents and pictures to communicate with foreign exhibitors and travel agencies. In 2011, Inner Mongolia sent delegators to attend the World Heritage Travel Expo. During the exhibition, the delegators shared brochures and video clips of Mongolian cultural heritages to the world. By making full use of the platform of international tourism exhibition, Inner Mongolia has attracted a lot of foreign tourists and experts to travel and investigate. In this process, intercultural communication can't exist without translation. Effective and accurate transformation of the charm of unique ethnic culture can't happen without high quality English translation materials. Unfortunately, Inner Mongolia should give more focus on recognition and practice of translating cultural heritage. According to the investigation, till now Inner Mongolia has very few relevant published translation materials about the historical and cultural heritage publicity.

There are many problems in existing $\mathrm{C}-\mathrm{E}$ translation of cultural heritage publicity. The translation material about Mausoleum of Genghis Khan, for example, is quite limited. So this paper aims to focus on the translation material collected from scenic spots and the Mausoleum's official website. The critical problem of the English translation is superficial translation of the information and the neglect of the implied cultural connotation. Some translations wrongly render words and terms of the ethnical source texts which definitely leads to mistranslation. And some translations are redundant with. Eventually, these problems will lower the readability of English translations and undermine the effect of foreign publicity of cultural heritage.

\section{Language Characteristics and Style Differences Between Chinese and English Publicity Materials}

Both the Chinese and the English language are different in cultural backgrounds, concepts of values and thinking modes. They are also different not only in words formation, sentence structures, and discourses, but also in language styles. For Chinese, people often choose rhetorical devices, idioms, and various figures of speech to perfect the expression of the language. While for English, it emphasizes strict logic s, refined expressions but simple literary forms. One of the usual mistakes in foreign publicity translation of intangible culture, it often uses many modification to make exaggerating atmosphere and displays the beauty of the language. For example:

(1) 成吉思汗祭祀形式独特, 内容丰富, 内涵深刻, 是蒙古民族文化之源头和结晶。成吉思汗陵, 是蒙古民 族历史文化的摇篮, 祖国民族优秀文化瑰宝, 人类珍贵的文化遗产。

Tr: Genghis Khan's sacrificial ceremony, which is unique in form, variety in content and rich in connotation, reveals the source of Mongol culture. Not only is Genghis Khan's Mausoleum a holy cordial of Mongolian culture, but it is also a valuable cultural treasure of nation and peculiar cultural heritage of mankind.

In the Chinese version, there are metaphors “结晶” “摇篮” “瑰宝”to modify the important meanings and position of Genghis Khan's sacrificial ceremony and Genghis Khan's Mausoleum. But in the English text, it omits the translation of "crystal" and "cradle", on the contrary, directly translated as "the source of Mongol culture" and "a holy cordial of Mongolian culture". Besides, the English text is highly structured, "a holy cordial of Mongolian culture", "a valuable cultural treasure of nation" and "peculiar cultural heritage of mankind". The structure is symmetrical in form and embodies the aesthetic function of English language.

The Chinese and the English language are different in language characteristics and styles, therefore, in $\mathrm{C}-\mathrm{E}$ translation of foreign publicity, translators should take full account of language differences, and use some translation strategies to adjust the target text on the premise that it won't change the meaning of source text. Such adjustments will ensure the translation to conform more to the English expression style and be closer to the target reader thinking habits. What's more, the translation provides easy access to the publicity content and achieves desired effect of foreign publicity (Yuan, 2005, p.76).

In the light of Chinese style, the current translation is hard for target readers to understand the original meaning and fail to reach purpose and effect of foreign publicity. Therefore, in those $\mathrm{C}-\mathrm{E}$ translations, translators are better to follow the principles below to tackle language differences and make translations easier for target readers to accept.

(1)Help target readers acquire information quickly and accurately as the primary goal (Shi, 2012, p.135).

One of the objectives of foreign publicity is to let foreign readers absorb the essence of the source text in the shortest period of time, which requires the translation is concise and comprehensive to provide accurate information. If the translation is excessively modified, it will let some foreign readers lose interest in continuing reading because it is hard to understand. So the priority is to draw the readers' eyes to the translation. 
(2) Give full consideration to target reader's aesthetic habits and earn their recognition (Shi, 2012, p.135).

The Chinese language is accustomed to using high-sounding words and is good at flowery expressions, neat and balanced forms and cadence sentence structures, while the English language focuses on rigorous logics, compact structures and precise expressions. The translation in strict accordance with Chinese style seems to be flashy without substance, and gives an inaccurate and exaggerated impression, which doesn't conform to foreign readers' aesthetic value-orientation, and makes foreign readers doubt publicity information's reliability and is unable to get their recognition.

\section{ANALYSiS AND SUgGestion OF TRANSLATION PROBLEMS}

Based on the careful study and analysis, the author discovers that the translation of publicity materials of Genghis Khan's Mausoleum not only embodies the fundamental principles and function of translation, but also spreads Chinese minority culture with simple and plain language. At the same time, some translation problems can be divided into the following categories: spelling mistakes, grammatical errors, mistranslation, transliteration without annotation and redundancy.

\section{A. Spelling Mistakes}

The common spelling mistakes include misspelling, letter missing, and misusing capital letters and small letters. And these mistakes show that the translator is careless and the relevant supervision from institutions is rather ineffective.

\section{Misspelling}

TT16. With continually enlarging and remedy the Genghis Khan Mausoleum became a famous spot of history and culture showing the majestic appearance.

ST16.作为著名的历史文化景点, 成吉思汗陵经过不断地扩建和重修展现出了雄伟的外观。

In this sentence, we can easily finger out that "continuesly" is wrong spelled instead of "continuously".

TT17.The five -color is symbol of the various ethnic groups commanded under Genhis Khan.

ST17.五种颜色象征着成吉思汗掌管下的不同族群。

In TT17, Genhis Khan is wrongly spelled as "Genghis Khan", and the same misspelling appears in the second part of the official website- "Historical Vicissitude".

There are also many misspelling words, such as "milk barral", "vise chairman", "standerd", etc.

\section{Letter Missing}

TT18.Genghis Khan is the highst God worshipped by Mongolians.

ST18.成吉思汗是蒙古族人民心中最伟大的神。

In TT18, the word "highst" should be "highest", which loses letter "e"in the middle.

TT19.Worshipping palace was built for him and the Ordos people were assigned as guard and take resposibility for sacrifice from then on.

ST19. 蒙古族人民为了纪念成吉思汗修建了这座陵宫, 鄂尔多斯人民从修建之初成为成吉思汗陵的守护者, 并 承担起祭祀的重任。

In TT19, the word "resposibility" misses the letter "n", and it should be "responsibility".

\section{Misusing the Capital Letters and Small Letters}

TT20.The five lucky colors of the hada presented to Genghis Khan.

ST20.向成吉思汗呈现的哈达有象征吉祥的五种不同的颜色。

TT21.Management Committee Of Genghis Khan

ST21.成吉思汗陵管理委员会

In TT20, "Hada" here is a proper noun, so the first letter should be capitalized as Hada or translated as Khata. And TT21 is the title of the fifth part of its official website, and it is well known that the first letter of preposition in the title shouldn't be capitalized, so "Of" should be corrected as "of".

\section{B. Grammatical Errors}

Grammatical errors include lacking of articles or misusing of articles, lacking of conjunctions, voice and speech errors.

\section{Misuse of Articles}

TT22.The Management Committee of Genghis Khan Tourist Site handles official affairs jointly with the Genghis Khan Administration Bureau, which is a agency of Ordos government.

ST22. 成吉思汗陵旅游区管理委员会与鄂尔多斯政府的成吉思汗陵园管理局共同管理成吉思汗陵的管理事务。

It is generally known that article "an" should be used before the vowels. So an article "as" should be added before the word "agency" instead of the word"a".

\section{Lack of Conjunction}

TT23.The Mausoleum of Genghis Khan was authorized by the State Department as the second key historical sites, it is also one of the 40 bests of Chinese places of interests.

ST23.成吉思汗陵是国务院授予的重点文物保护单位, 中国旅游胜地四十佳。 
It is a rule that if a sentence consists of two clauses, the second one should be connected by a conjunction or a relative. TT23 consists of two clauses, so the linking word like "and" or "then" should be added.

3. Voice Errors

TT24.In about 1170, his father was kill with poison by Tatar tribe.

$\mathrm{ST} 24$.大约 1170 年, 成吉思汗的父亲被塔塔尔部落毒杀。

From the above example, the meaning is to show us that Tatar tribe killed Genghis Khan's father, so when "his father" is used as subject, the predicate should use a passive voice rather than an active voice. Therefore, this sentence should be corrected as "His father was killed with poison by Tatar tribe".

\section{Speech Errors}

TT25.The trade between east and west after the conquer to the west brought Chinese culture to Europe, brought them prosperous.

ST25.征战西方国家之后，中西交流将中国文化带到了欧洲促进了当地的繁荣。

In the double object construction, we use a noun or a noun phrase as its direct object. While in TT25, "prosperous" is an adjective, and it should be corrected as the noun form "prosperity".

\section{Mistranslation}

TT26.The fantastic main palace shaped as a flying eagle, symbolizing the Genghis Khan's spirits of fearlessness and forthgoing.

ST26. 宏伟的主殿像一只秵翔的雄鹰，象征着成吉思汗震撼山河的气度。

In TT26, “forthgoing" is always used as an adjective word, meaning "friendly" or "forward". While according to the meaning of context, what is needed here is a synonym of fearlessness to show Genghis Khan's spirit. so we can choose "courageousness" or "bravery" instead.

TT27.On the tool of the sacrifice, the valuable and special scarifyicing containers are produced, showing the Mongolian people`s fondness of nature and animals.

ST27.独特的祭奠形式和珍贵特别的祭祀器具展现了蒙古族人民对自然和动物的喜爱之情。

In TT27, "Scarifying" is a gerund form of verb "scarify", and the meaning of "scarify" is "to plow up the soil" or "to criticize". However, both meanings don't fit the textural meaning. "Sacrifice" is a better choice.

TT28.There is a shining board with the golden letters of "The Mausoleum of Genghis Khan" written by Wulanhu in 1985.

ST28.牌坊式大门上端悬挂着原国家副主席乌兰夫题写的“成吉思汗陵”石雕牌匾, 显得格外庄重。

And in TT28, "Wulanhu" should be corrected as “Ulanhu” based on Mongolian pronunciation.

\section{Incorrect Information}

TT29.The Mausoleum, which symbolizing Genghis Khan lies in the Gander Oboo in YijinHoro Banner of Ordos City in $109.40 \mathrm{E}, 39.23 \mathrm{~S}$ at an altitude of $1350 \mathrm{~m}$.

ST29. 成吉思汗陵, 坐落在鄂尔多斯市伊金霍洛旗伊金霍洛苏木境内。（东经 109.40 度, 北纬 39.23 度, 海拔 1 千 350 米)

It is a common sense that Mausoleum of Genghis Khan is a part of China, so there is no doubt that Mausoleum of Genghis Khan is located in the Northern Hemisphere. While "39.23S" stands for 39.23 degrees south. In TT29, it uses $39.23 \mathrm{~S}$ instead of $39.23 \mathrm{~N}$, so it is a basic mistake which be avoided.

ST30.纳石失大袍

TT30.textured loss robe

In ST30, “纳石失” is a Persian, and it means “gold thread”. It is wrong to translate “纳石失大袍” as “textured loss robe", but translated as "robe made of gold thread".

\section{TRanslation Methods ReCOnsidered}

According to the differences in Chinese and English language characteristics and styles, in the translation materials of Genghis Khan's Mausoleum, the translator adopted different translation methods to deal with the specific cultural concepts, proper nouns, special terms and professional and complex expressions. And the most frequently used translation methods include addition, omission, combination and division, the combination of transliteration and semantic translation. In the following analysis, the first example in the original text will be marked by ST1, and the translation translated as TT1 correspondingly.

\section{A. Addition}

Among various techniques, addition is one of the most commonly used methods and is indispensable to a better result of translation. Addition is to add necessary words in translation to adhere to the faithful representation of the original version. Addition often serves to the translation of the culture-specific words, proper names and technical terms, and it can further explain terms, enhance the coherence of the text, complement the underlying background information, and so on (Zhang \& Chen, 2013,p.102) 
Firstly, most of foreign tourists don't understand some translation of technical terms and unique expressions. For instance, the ancient dynasty names, reign titles, historical periods, ancient Chinese official titles, historical stories, etc. The translation of such words needs addition to deal with the semantic voids caused by cultural default (Di, 2013, p.56).

Addition adopted in the translation of historical figures can avoid foreigners' misunderstanding and help them know the necessity of mentioning these people here. For example:

ST1.窝阔台

TT1.Dogged, successor of Genghis ended Jin Dynasty in 1234.

The above case shows that when translating the ancient name, adding some information about this person's achievement or some other relevant information can help foreign tourists better understand this person himself. In TT1, the addition "successor of Genghis ended Jin Dynasty in 1234" helps foreigners to know what the relationship between Ogedei and Genghis Khan. The addition makes foreign readers roughly know whether they need to consult other materials to obtain sufficient knowledge about this person.

The translations of place names as well as the translation of historical figures play an important role in translation practice, communication. For some place names, they shouldn't be translated superficially, but rather determined according to its cultural background and context. And adding some information about geographic position or some relevant background information can help foreign tourists know its importance, otherwise, they will misunderstand as an ordinary place.

ST2.鄂尔多斯平原

TT2. The Ordos Plateau, surrounded by Yellow River which breeds the race is naturally linked with Genghis Khan who is not only buried here but also brought glorious culture of Mongolians.

ST3.九十九级台阶

TT3. The blessed stair of ninety-nine stairs"(The blessed stair of ninety-nine stairs" is one of the scenic spots of Genghis Khan' Mausoleum).

The added information in TT2 shows us the approximate position of Ordos Plateau and it lets us know that it is associated with Genghis Khan and considered as the holy place by Mongolians. In TT3, the addition shows us that these ninety-nine stairs stand for happiness, affluence and auspiciousness.

Compared with the translation of person names and place names, translation of ancient political systems needs more addition to make them clear to readers. Because some of the names are difficult to understand even for source language readers without enough historical knowledge, let alone the target language readers. And addition can solve this problem somehow; it can help foreigners have a rough idea about what it is and what the main function is. For example:

ST4.大札萨

TT4.Great Zhasha- the great law

ST5.成吉思汗实行千户制, 打破部落专制制度.

TT5.Genghis Khan carried out the governing system of thousand units and smashed the autarchy system.

In ST4, “大札萨” is a professional term with national characteristics, it is even harder for the Chinese people to now the real meaning behind it. Foreigners who are lack of knowledge about Mongolian history and culture fell puzzled in reading the translation. In TT4, it adds the basic background information "the great law" to help readers know that “大 札萨”is the Mongolian's written code of law. In TT5, “千户制” is a unique word of Mongolian word, and it is Mongol khanate's system to unite military with politics. However, its special content is unfamiliar to foreign tourists, so a word-for-word translation (thousand units) is unintelligible. Therefore, we must add some information to make it easier for readers to accept. It can be translated as Mingghan (a Mongol regiment of 1,000 men created by Genghis Khan).

\section{B. Omission}

The Chinese language often uses abundant rhetoric devices to describe things vividly, while the English language tends to emphasize concise content, precise structure, accurate information, and natural language. Therefore, it is useful to omit some words or expressions in certain contexts. If the meaning conveyed by a peculiar word or expression is not necessary to be mentioned in understanding the translation, translators use this strategy to avoid lengthy explanations and foreign tourists' auditory and visual fatigue.

The Chinese language often uses many adjectives to modify something, so it makes foreigners confused and fail to catch the main point. On the contrary, omitting some words can help foreigners grasp main point easily and quickly. For example:

ST6.后来在这里“营造永世坚固的八白室”，成为“全体民众的总神袛”。

TT6.Later the Eternal Eight White Houses were built here and became the head sanctuary for the general citizens ever since.

"Eight White Houses" is another name of Genghis Khan's Mausoleum, and it is majestic and composed of eight white buildings with strong Mongolian style. In TT6, there are two reasons to translate it as "Eternal Eight White House", and leave "solid" out. Firstly, "solid" is the common and necessary property of all the buildings and it is not an exception to Genghis Khan's Mausoleum, so it is not essential. Secondly, the word "eternal" reflects the Mausoleum's quality that it is hard to erode and can remain for a long time. The word "eternal" also emphasizes the Mausoleum's 
eternal significance and influence, and shows that it will be cherished by Mongolian people forever. So the omission of "solid" can make translation have rich implication.

If the information of the source language has a long history and many hidden meanings, translators need to think carefully about the message, and whether it needs a long way toward explicating it. And translators should adhere to the principle that keeps the most effective information rather than something useless. For example:

ST7. 商更斡尔阁白宫, 是成吉思汗八白室之一，原为一座宽敞的宫帐搭在成吉思汗伊金宫帐的旁边。作为八白 室的珍藏白宫, 主要存放守灵者达尔扈特人出游募化携带的成吉思汗画像, 剑, 祭灯, 银碗等一套祭祀成吉思 汗的用品。还保存着金银, 珠宝祭皿及蒙古民族的历史文献和祭奠成吉思汗的各种有关书籍, 其中主要有“白史”, “红史”, “黄史”, “金册”等。

TT7.Shang Gen Wu Erger White Chamber means collection chamber in Chinese. It is one of the Ba Bai Shi (the eight white chambers) which mainly keeps sacrificial articles and document of Genghis Khan and so on (The Brochure of Genghis Khan's Mausoleum, Page 2).

ST8. 每逢农历三月二十一，成吉思汗春季大祭奠天仪式就在这里举行。这里立有成吉思汗金马桩和巴图吉勒 (系马练绳) 。每逢春季查干苏鲁克大祭期间, 供奉成吉思汗神马, 并系有九十九匹白骡马和马驹, 以白骡马之 乳祭祀苍天。

TT8.Genghis Khan's Spring Ceremony of worshiping heavens is held in March, 21st in lunar calendar every year. Genghis Khan's golden horse peg is placed there. This is also the place where Genghis Khan's holy horses are worshiped (The Brochure of Genghis Khan's Mausoleum, p. 4).

In TT7, the translation omits the respective translations of portraits, swords, lamps and silver bowls, because they belong to the sacrifices. And “白史，红史，黄史” all belong to the Mongolian history documents, so it is not necessary to itemize them one by one. And each of them contains cultural information, so it will take up too much space to explain clearly one by one. Therefore, omission used here is a more appropriate method. In TT8, the description of latter part of the original sentence just wants to say that those horses fighting alongside Genghis Khan in the battle field are holy and worshiped. And Cha Gan Su Lu Ke Sacrificial Ceremony is the same as the previously mentioned: Genghis Khan's Spring Ceremony of worshiping heaven. So omission used here can avoid redundancy.

The Chinese tourism text usually has different rhetorical devices, like metaphor, simile, hyperbole and personification, while these rhetorical devices carry little information. Comparing with it, foreign tourists like the text in concise language with well-organized structure. Therefore, on the premise of conveying the source cultural message correctly, English version often omits lengthy content which is useless for the understanding. For example:

ST9. 成吉思汗陵园门牌楼, 是进入成吉思汗陵园的标志。乳白的颜色, 是纯洁的象征, 吉祥的祝福, 像一条 洁白的哈达, 欢迎远方的客人, 祝福人们吉祥安康。牌坊式大门上端悬挂着原国家副主席乌兰夫题写的“成吉思 汗陵”石雕牌匾, 显得格外庄重。

TT9.Genghis Khan's Mausoleum's Decorated Archway is a landmark of the mausoleum, the color of white, which contains the meaning of purity and blessing, expresses the warmest welcome towards the guests from far and near. The plaque with the characters of Genghis khan's mausoleum, which was written by the former vice-chairman of the nation, Ulaanlwu (http://www.cjshl.com:81/News_View.asp?NewsID=32 2007/8/26).

In the Chinese version, it compares the color of Decorated Archway to the white hada. This usage just wants to show the color of Decorated Archway is white instead of other unique meanings, so in order to keep foreigners from unnecessary confusion, it uses "the color of white" in the translation version, which contains the meaning of purity and blessing" instead of the simile usage. And in ST9, it repeats "blessing" twice, while in the translation, it omits the second one to avoid the encumbrance and repetition.

\section{Combination and Division}

Simply speaking, the difference between the Chinese and English language structures are that the Chinese one often uses loose short sentences, repeated expressions and four-character sentences, while the English one commonly uses logical long sentences, well-knit structures and direct expressions. For this reason, combination and division are often used to adjust sentence structures in the translation, in order to accord with the English expression patterns.

Tourism translation should try to be brief and to the point, so it often divides complex sentences into simple sentences which are much easier to understand without confusion. For example:

ST10. 商更斡尔阁白宫里珍藏着各种金银祭器以及 $\{$ 金书 $\}$ 等蒙古民族历史文献书籍，东殿绘有“世界巨人”大幅 壁画，再现了成吉思汗建立横跨亚欧的蒙古大帝国的伟业。

TT10.Also this palace collected some gold and silver sacrificial utensil and Mongolia nation historical book. On the wall, the large fresco was painted that has the "world giant". This fresco have reappeared the great affair that Genghis Khan established the big country over Asia- Europe.

Comparing with the original text that uses one sentence to introduce the Shang Gen Wu Erger White Chamber, the translator divides the complex sentence into three short ones which is more in line with well-structured feature of English language. This translation is faithful to the original, at the same time, it makes a clear impression on foreign tourists. 
Contrary to the division is combination. When introducing the tourist attractions, it often illustrates the geographical location and history. In general, an English sentence has clear and well-arranged structure with many principal and subordinate relations and minor constituents are often expressed with prepositional phrases or participial phrases. For example:

ST11. 高大的成吉思汗出征铜像, 再现成吉思汗西征时赞美鄂尔多斯是“梅花鹿儿栖身之所, 戴胜鸟儿育雏之 乡, 衰落王朝振兴之地, 白发老翁享乐之邦”的情景和崛起于马背上的伟人震撼山河的气度。铜像高 6.6 米, 广 场直径 66 米, 寓意成吉思汗寿年。

TT11.Genghis khan's bronze statue, which is $6.6 \mathrm{~m}$ in height, stands in the center of the square which is $66 \mathrm{~m}$ in diameter, overlooking this land and as if saying this is the place where deer inhabits themselves, bird nurtures their young, dynasties rise up into their strength and old people enjoy their lives.

(http://www.cjshl.com:81/News_View.asp?NewsID=33 2007/8/26).

In ST11, it uses two sentences to introduce Genghis Khan's bronze statue, while in TT11, it has adjusted word order, and used a parenthesis to show the height of bronze statue and a subordinate clause to introduce the diameter of the square. It combines two sentences into one which is closer to foreign readers' reading habit.

\section{The Combination of Transliteration and Semantic Translation}

Transliteration is a commonly used translation method to deal with cultural differences, and it is very important to keep source language's language and culture characteristics. However, to avoid over-foreignization caused by using transliteration blindly, translators often use transliteration and semantic translation in the translation of cultural heritage (Chen, 2011, p.42). Generally speaking, in the translation of specific cultural words, transliteration and semantic translation are commonly used methods if there are no corresponding words in the target language.

ST12.吉劳

TT12.Jilao (bridle)

ST13. 胡日萨德格

TT13.Hurisadege (bow and arrow)

ST14.宝日温都

TT14.baoriwenduer (milk barrel)

ST15.查古

TT15.Chagu(copper ware used as wine set)

“吉劳”, “胡日萨德格”, “宝日温都”are Mongolian cultural words, and there are no equivalent words in English language system. Transliteration helps foreign readers understand the mandarin pronunciation of these cultural words and adding semantic translation can transmit these words' meaning and represented function to foreign readers. Therefore, the combination of transliteration and semantic translation can convey information more accurately, and can be much easier for foreign readers to understand.

\section{Suggestion For IMPRoving the Quality of Intangible Cultural Translation}

Tourist industry is a new field of culture exchange with the fastest developing speed in recent years. And cultural heritage is the basic tourism resource, a scroll to show human civilization, and a spiritual pillar to support the average people in the modern world. Therefore, the foreign publicity of cultural heritage is beneficial to disseminate the Chinese long history, carry forward national spirit, as well as show socialism with Chinese characteristics, and build harmonious national and international relations (Chen, 2006, p.51). Translation, as an indispensable means of foreign publicity, contributes to strengthening the exchanges and mutual understandings between China and the world by transferring information and disseminating culture. And the translation of cultural heritage publicity plays an important role in advertising and protecting culture heritage. However, due to differences between the Chinese and the English language characteristics and styles, translation of cultural heritage publicity faces many problems. So translators should adopt different translation strategies to achieve desired publicity effect. The commonly used strategies include addition, omission, the combination of transliteration and semantic translation, which are useful for foreign readers to understand unique national and historical cultural heritage. However, there are many translation problems such as misspelling, grammar errors and misuse of articles. And translators can avoid these problems if they are careful enough. Successful translation can not only exchange cultural heritage's surface information from one language into another language, but also exchange different cultures. Therefore, translators need to improve their culture awareness and strengthen their own self-cultivation towards professionalization and adopt different translation strategies to make the translation accepted by the target readers more easily. High quality translation of cultural heritage publicity can attract more foreign visitors and experts from all over the world. All in all, the translation of cultural heritage publicity should be enhanced, and specialized agencies established to supervise the translation work.

To better publicize Mongolian culture, and set up a good image of the city, it is necessary for us to improve the translation quality of publicity materials. Language can reflect the civilization degree of a city, while there are many translation problems existing in the Mausoleum of Genghis Khan's publicity materials. So it is very urgent to improve and promote the English translation. We can deal with these problems according to the following aspects. The First step 
is to improve translator's cultural training. The quality of translation largely depends on the translator's quality, so we need to organize a group of scholars who are good at translation and have a good knowledge of tourism materials to in charge of the translation. The second step is to establish a set of normative standards of tourism translation. Scarce standards lead directly to the uneven quality of the translation, so the authority should move to standardize English translations in the scenic spots, exhibitions, menus, and hotel service (Zhang et. al., 2010, p.4).

\section{REFERENCES}

[1] Chen, F.R. (2011). Difficulties and Countermeasures of English Translation of Chinese Intangible Cultural Heritage. China Science Translation, 2, 41-45.

[2] Di, F. (2013). Translation Strategies of Electronic Audio Commentary: A Case Study of Shannxi Musume. The Liaoning Industrial University Journal (Social Science), 3, 54-58.

[3] Shi,N.X. (2012). A Study on the Style Differences Between Chinese and English from the Perspective of Foreign Publicity Translation. Modern Chinese, 7,135-137.

[4] Yuan, X.N. (2005). Reasons and Strategies of International Publicity Translation. The Chinese Translator, 1, 75-78.

[5] Zhang, Meifang \& Chen, Xi. (2013).Transmiting the Message to Meet the Readership: A Case Study of the Website of the Imperial Palace. The Chinese Translator, 4, 99-103.

[6] Zhang, Y. Q., Lv H.Y. \& Feng H.Z. (2010).An Investigation and Countermeasures of Current Translation Situation of Tourism Scenic Spots in Lintong District of Xi'an. Overseas English, 7, 3-5.

[7] Zheng, Z. (2013). The Current Situation and Analysis of English Translation of Intangible Cultural Heritage in Hebei Province. Young Literate, 2,181.

Jinyu Liu, Ph.D, Associate professor in the English Department of the Foreign Languages College at Inner Mongolia University, China. Research interest includes translation history studies, esp. East Asian translation history.

Meiling Wen, B.A., Intern in The Mausoleum of Genghis Khan, Er dos, Inner Mongolia. 